\title{
Welding of S960MC with undermatching filler material
}

\author{
Christian Schneider ${ }^{1}$ (I) $\cdot$ Wolfgang Ernst ${ }^{2} \cdot$ Ronald Schnitzer $^{3} \cdot$ Herbert Staufer $^{4} \cdot$ Rudolf Vallant $^{1} \cdot$ Norbert Enzinger $^{1}$
}

Received: 31 August 2017 / Accepted: 15 February 2018 / Published online: 9 March 2018

(C) The Author(s) 2018. This article is an open access publication

\begin{abstract}
High strength structural steels are in high demand thanks to their favorable mechanical properties. They offer high strength with sufficient toughness and good forming capabilities. Applications range from shipbuilding, to offshore constructions, cranes, and pipelines. A lot of current research focuses on weldability of high strength low alloy (HSLA) steels, especially improving the toughness in the weld zone, i.e., weld metal (WM) and heat affected zone (HAZ). In the present work, four different fusion welding processes using undermatching filler metal are compared on 8-mm thick sheets of S960MC structural steel. The welding processes include electron beam, laser hybrid, plasma, and gas metal arc welding. The welded joints are characterized by means of mechanical testing, tensile, impact, and hardness testing, and microstructural investigaton, light optical, and scanning electron microscopy. Furthermore, microprobe analysis of the weld metal was used to investigate the chemical composition of the weld metal.
\end{abstract}

Keywords High strength structural steel · Electron beam welding · Laser beam welding · Plasma beam welding · Undermatching filler material

\section{Introduction}

The use of high strength low alloyed (HSLA) structural steels, such as S960MC, is steadily increasing in engineering

Recommended for publication by Commission IX - Behaviour of Metals Subjected to Welding

$\triangle$ Christian Schneider

christian.schneider@tugraz.at

Wolfgang Ernst

wolfgang.ernst@voestalpine.com

Ronald Schnitzer

ronald.schnitzer@unileoben.ac.at

Herbert Staufer

staufer.herbert@fronius.com

Rudolf Vallant

rudolf.vallant@tugraz.at

Norbert Enzinger

norbert.enzinger@tugraz.at

1 Institute of Materials Science, Joining and Forming, University of Technology Graz, Graz, Austria

2 voestalpine Stahl GmbH, Linz, Austria

3 Department of Physical Metallurgy and Materials Testing, University of Leoben, Leoben, Austria

4 Fronius International GmbH, Wels, Austria industry. Typical applications are structures in load handling, transportation vehicles, and lifting equipment, such as telescoping booms and cranes. The higher strength of the material offers increased payload and/or reduced weight of structures compared to standard structural steel [13, 18]. Welding of HSLA steel however, is more demanding than normal structural steel since the process window of heat input and cooling rate is smaller. Nevertheless, it has been proven that this steel can be welded successfully with suitable welding methods, such as laser beam, laser hybrid, or modern gas metal arc welding [2, 4-6]. Also, the filler metals play an important role in the welding of HSLA steels [15]. Guo et al. [5] were able to weld 8-mm thick sheets of S960 HSLA steel plates in a single pass using autogenous laser welding. They obtained welds with sufficient strength but reduced toughness in the weld metal compared to the base material. Guo et al. [6] also investigated gas metal arc welding of S960 HSLA steel using matching filler metal on 8-mm thick sheets. These joints exhibit better impact toughness in the weld metal compared to the laser welds but do not reach the necessary strength level since the welds broke in the soft HAZ.

The focus of this work is to investigate $8-\mathrm{mm}$ thick welds, produced with different welding techniques, i.e., electron beam, laser hybrid, plasma, and gas metal arc welding, using undermatching filler metal and compare it to 
Table 1 Chemical composition of S960MC, wt $\%$

\begin{tabular}{llllll}
\hline $\mathrm{C}$ & $\mathrm{Si}$ & $\mathrm{Mn}$ & $\sum \mathrm{Cr}, \mathrm{Ni}, \mathrm{Mo}$ & $\mathrm{Cu}$ & $\sum \mathrm{V}, \mathrm{Nb}, \mathrm{Ti}$ \\
\hline 0.09 & 0.12 & 1.69 & 1.63 & 0.03 & 0.14 \\
\hline
\end{tabular}

reference GMA welds with matching filler metal (industrial standard).

\section{Materials}

Sheets of structural steel S960MC with a thickness of $8 \mathrm{~mm}$ were used for the welding experiments. S960MC is a microalloyed, thermomechanical-processed high strength structural steel, with a microstructure consisting mainly of martensite and tempered martensite. Basic mechanical properties and chemical compositions are given in Tables 1 and 2 . The chemical composition and mechanical properties of the filler metals used $(\varnothing=1.2 \mathrm{~mm})$ are listed in Tables 3 and 4.

\section{Methods}

\subsection{Welding procedure}

Various welding techniques were used to join 8-mm thick sheets of S960MC steel. Table 5 lists the weld seam geometry, number of passes, heat input, and measured $t_{8 / 5}$ times for the examined welding processes, electron beam welding, laser hybrid welding (LHW), plasma welding with cold-wire $(\mathrm{PW}+\mathrm{CW})$, and gas metal arc welding. RP stands for root pass and FP for filler pass. Figure 1 shows schematic drawings of the two different weld seam preparations, square groove (I), and single $\mathrm{V}$ groove $(\mathrm{V})$. The reference sample was welded with standard GMAW using the matching filler metal (M). For all other processes undermatching (UM) filler metal was used.

\subsection{Characterization of welds}

For each welding process, three flat bar tension specimens were tested according to DIN EN ISO 6892-1 [9]. The

Table 2 Nominal mechanical properties of S960MC

\begin{tabular}{llll}
\hline Yield & Tensile & Fracture & Impact toughness \\
strength & strength & elongation & @ $-20{ }^{\circ} \mathrm{C}$ \\
$\mathrm{MPa}$ & $\mathrm{MPa}$ & $\mathrm{J}$ & $73 \pm 18$ \\
\hline 988 & 1014 & 10.9 & 73
\end{tabular}

Table 3 Chemical composition of the filler metals G4Si1 (undermatching, UM) and G 895 Mn4Ni2.5CrMo (matching, M), wt\%

\begin{tabular}{lllllll}
\hline Filler metal & $\mathrm{C}$ & $\mathrm{Si}$ & $\mathrm{Mn}$ & $\mathrm{Ni}$ & $\mathrm{Cr}$ & $\mathrm{Mo}$ \\
\hline G4Si1 (UM) & 0.1 & 1.0 & 1.7 & - & - & - \\
G 89 5 Mn4Ni2.5CrMo (M) & 0.12 & 0.8 & 1.9 & 2.35 & 0.45 & 0.55
\end{tabular}

samples are grinded to a thickness of $6.3 \mathrm{~mm}$ to remove any weld imperfections, such as undercut, shrinkage groove, distortions, or misalignements.

Sub-size charpy V-notch specimens, with a dimension of $10 \times b \times 55 \mathrm{~mm}$, were used for impact testing according to DIN EN ISO 148 [7]. The width $b$ depended on the imperfections, e.g., undercut, shrinkage groove, distortion, misalignements, and varied from 7.3 to $7.7 \mathrm{~mm}$. There are a number of investigations on the subject of correction for sub-size charpy specimens $[3,11,16,17]$. Chao et al. [3] tested the toughness of DP590 steel using sub-sized charpy specimens with a reduced width of $5.5 \mathrm{~mm}$. They postulated that the only necessary correction is for the reduced thickness and therefore multiplied their test data by a factor of 1.82 (i.e., $\frac{10}{5.5}$ ). Since we have a similar situation, as the only nonstandard dimension is the reduced specimen thickness, we increased the recorded values by the factor $\frac{10}{b}$, representing the area ration of our specimens. The V-notch was machined perpendicular to the surface with the 2-mm deep root located in the center of the weld (VWT 0/0) [1]. Three samples were tested each at -20 and $-40{ }^{\circ} \mathrm{C}$.

The hardness distribution in the fusion zone was determined by Vickers hardness testing HV 10 [8]. For HV 10 two lines, running in a zigzag pattern, to reduce the horizontal spacing, were carried out per specimen. The measurement lines were positioned approx. $2 \mathrm{~mm}$ from the top respectively bottom surface. The individual indents are $1 \mathrm{~mm}$ apart.

For light optical microscopy, the polished cross-sections were etched with Nital $\left(\mathrm{HNO}_{3}\right)$ and LePera reagent [10]. The Nital etching facilitates the differentiation between WM, HAZ, and BM, whereas the LePera color etching was used to determine the different microstructures in the weld.

Table 4 Nominal mechanical properties of G4Si1 (UM) and G 895 Mn4Ni2.5CrMo (M)

\begin{tabular}{|c|c|c|c|c|}
\hline $\begin{array}{l}\text { Filler } \\
\text { metal }\end{array}$ & $\begin{array}{l}\text { Yield } \\
\text { strength } \\
\mathrm{MPa}\end{array}$ & $\begin{array}{l}\text { Tensile } \\
\text { strength } \\
\mathrm{MPa}\end{array}$ & $\begin{array}{l}\text { Fracture } \\
\text { elongation } \\
\%\end{array}$ & $\begin{array}{l}\text { Impact toughness } \\
@-20^{\circ} \mathrm{C} \\
\mathrm{J}\end{array}$ \\
\hline G4Si1 (UM) & $\geq 460$ & $530-680$ & $\geq 26$ & $\geq 47$ \\
\hline $\begin{array}{l}\text { G } 895 \text { Mn4Ni2.5 } \\
\text { CrMo (M) }\end{array}$ & $\geq 930$ & 980 & $\geq 14$ & $\geq 47$ \\
\hline
\end{tabular}


Table 5 Weld seam geometry, number of passes, filler metal, shielding gas, heat input and measured $t_{8 / 5}$ time for all examined welding processes

\begin{tabular}{lllllll}
\hline $\begin{array}{l}\text { Welding } \\
\text { process }\end{array}$ & $\begin{array}{l}\text { Weld } \\
\text { seam }\end{array}$ & & & $\begin{array}{l}\text { Fasses } \\
\text { material }\end{array}$ & $\begin{array}{l}\text { Shielding } \\
\text { gas }\end{array}$ & $\begin{array}{l}\text { Energy input } \\
\text { per unit } \\
\text { length J m }{ }^{1}\end{array}$ \\
\hline EBW+CW & I & 1 & UM & Vacuum & 0.263 & $0.8^{*}$ \\
LHW & I & 1 & UM & Corgon 18 & 0.412 & 2.9 \\
PW+CW & I & 1 & UM & Ar & 1.546 & 13.0 \\
GMAW & V & 2 & UM, M & Corgon 18 & RP: 0.605 & 6.5 \\
& & & & & FP: 0.633 & 9.5 \\
\hline
\end{tabular}

${ }^{*}$ This value was calculated using the formula in [12]

Scanning electron microscopy, on Nital etched samples, was also used to distinguish the different microstructures in the weld metal.

\section{Results and discussion}

\subsection{Tensile tests}

Figure 2 shows yield and tensile strength of welds of S960MC using different welding processes. OENORM EN ISO 15614-1 requires welds of S960MC steel to have the same tensile strength as the base material, i.e., 980$1150 \mathrm{MPa}$ [14]. The reference weld as well as the $\mathrm{EB}+\mathrm{CW}$, $\mathrm{LH}$ and $\mathrm{P}+\mathrm{CW}$ welds fulfill this requirement. The $\mathrm{EB}+\mathrm{CW}$, $\mathrm{LH}$, and reference welds always fractured in the base metal. The P+CW and GMA welds always broke in the base metal. The GMA welds with UM filler metal exhibit significantly lower yield and tensile strength and do not reach the requirements. Figure 3 shows all tested tensile specimens, and the fracture location is clearly visible.

\subsection{Impact testing}

DIN EN ISO 15614 requires a minimum impact toughness of $30 \mathrm{~J}$ at $-20{ }^{\circ} \mathrm{C}$. All tested welds exceed this limit, although the $\mathrm{EB}+\mathrm{CW}$ and $\mathrm{LH}$ welds are very close to the limit. The plasma welds are on the same level as the reference welds and reach 55-60 J. Even higher values were recorded for the UM GMA welds, which is not surprising due the significant lower strength level (Fig. 4). Figure 5 shows all tested specimens.

\subsection{Hardness testing}

Figure 6 shows hardness profiles for the $\mathrm{EB}+\mathrm{CW}, \mathrm{LH}$, $\mathrm{P}+\mathrm{CW}$, and GMA welds. The dotted blue and red lines represent the position of the indents. Both measurement lines, top (blue), and bottom (red) are positioned approx. $2 \mathrm{~mm}$ from the surfaces and run in a zigzag shape which makes it possible to decrease the horizontal distance of the indents.

For the $\mathrm{EB}+\mathrm{CW}, \mathrm{LH}$, and $\mathrm{P}+\mathrm{CW}$ joints the highest hardness occurs in the fine-grained heat affected zone (FGHAZ) and the lowest in the intercritical heat affected zone (ICHAZ). No significant hardness decrease in the subcritical zone, due to annealing during the production of the sheets, is observed. The EB+CW and LH welds show a significantly higher peak hardness when compared to $\mathrm{P}+\mathrm{CW}$ welds. The same influence can also be seen, to a lesser degree, at the minimum hardness in the ICHAZ. The hardness drop is slightly bigger for the $\mathrm{P}+\mathrm{CW}$ than for the LH welds. When comparing the two different gas metal arc welds, the influence of the filler metal can be clearly seen. The use of the undermatching FM leads to a significant hardness drop while the use of matching FM leads to a hardness increase in the weld metal. The higher alloying content of the matching FM is necessary, when using GMAW, to reach sufficient hardness and strength in the weld metal.

\subsection{Microscopy}

Each welding process results in a characteristic size and shape of the fusion zone, as can be seen in the Nitaletched microsections in Fig. 7. The shape of the fusion zone depends mainly on the edge preparation and the heat input. The low heat input and the square groove weld seam preparation of the $\mathrm{EB}+\mathrm{CW}$ welds lead to the characteristic I-shape and a narrow HAZ. With the exception of a small overlap on the top side of the weld, which occurred due to unsteady wire feed, the weld seam geometry is smooth on the top and root side of the weld. The LH welds exhibit a
Fig. 1 Schematic view of weld seam preparation, square groove (left), single V groove (right)

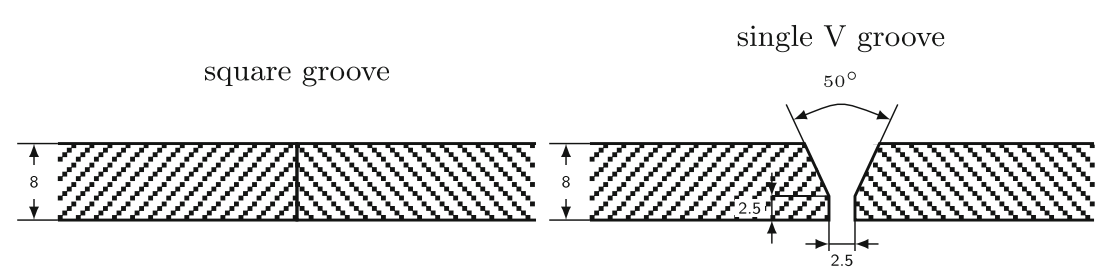


Fig. 2 Yield and tensile strength for all tested welding procedures with undermatching filler metal (solid). The reference welds were produced by standard GMAW and matching filler metal (hatched)
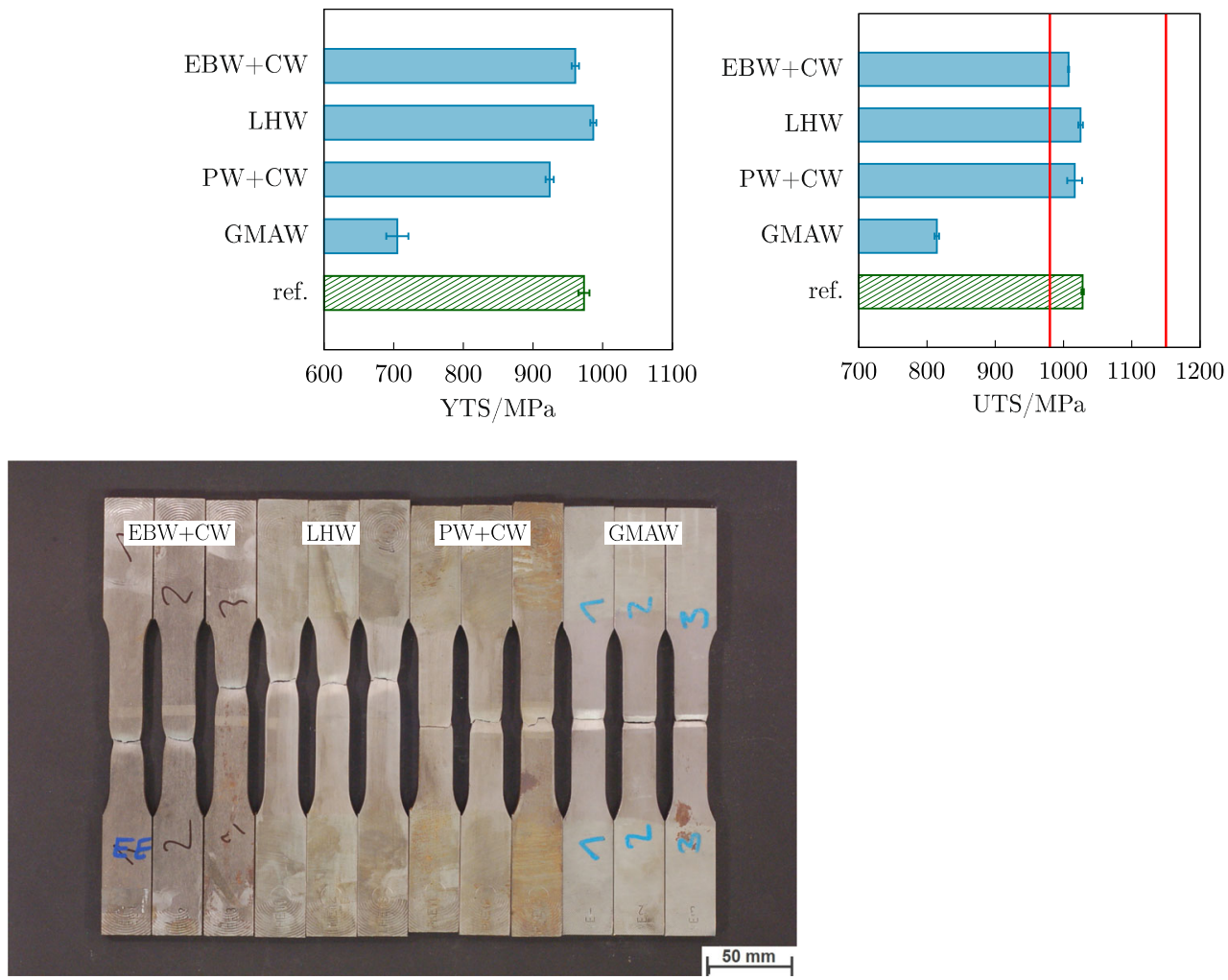

Fig. 3 Overview of all tested flat bar tensile test specimens. The fracture location is always clearly visible

Fig. 4 Impact toughness (VWT $(0 / 0))$ for all tested welding procedures with undermatching filler metal (solid). The reference welds were produced by standard GMAW and matching filler metal (hatched)

Fig. 5 Overview of all tested sub-size charpy V-notch samples. Notch location is in the center of the weld (VWT 0/0)
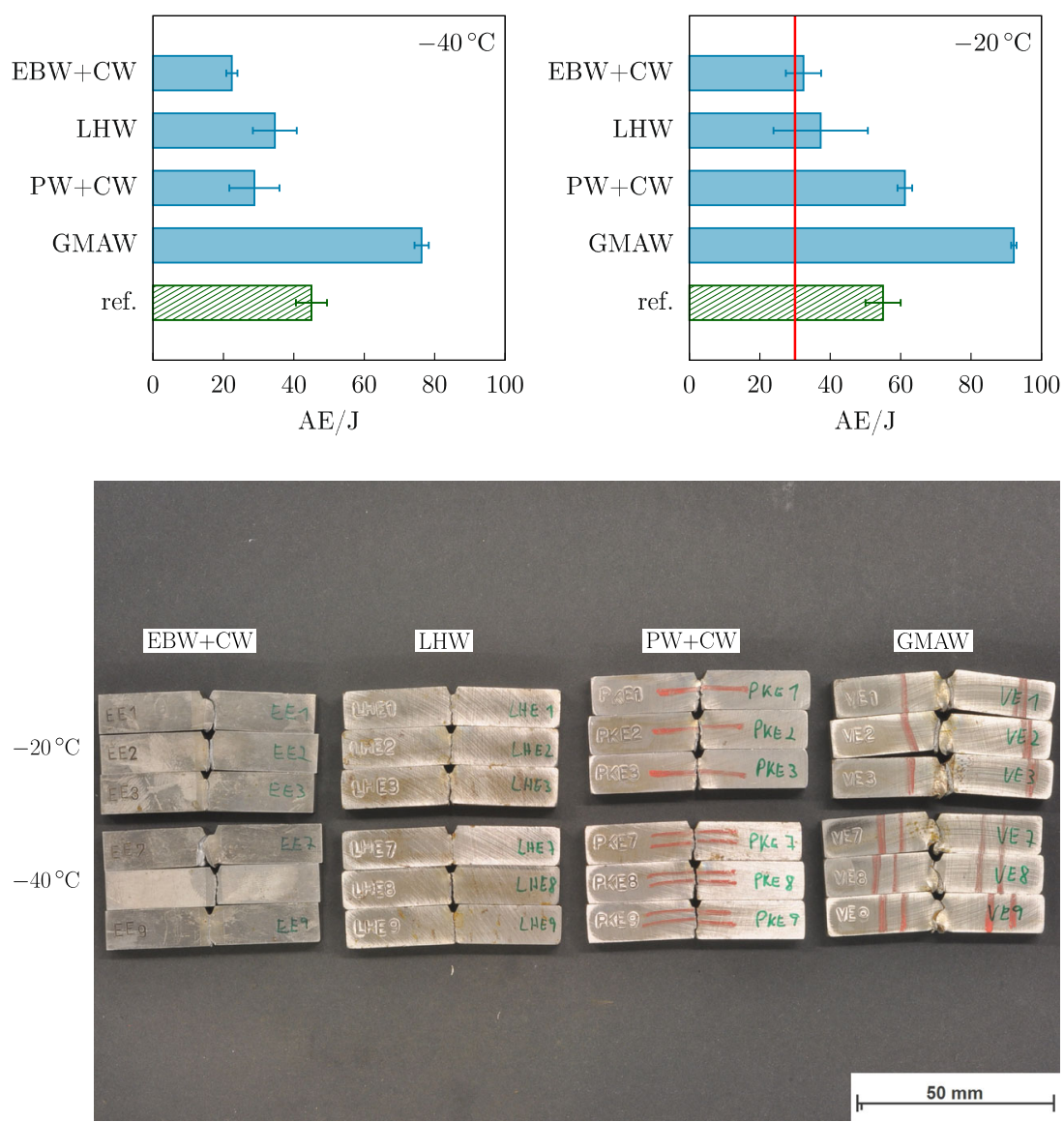
Fig. 6 Hardness lines (HV10) for all tested welding procedures. The dashed blue and red lines represent the position of the indents. Both measurement lines, top (blue) and bottom (red) are positioned approx. $2 \mathrm{~mm}$ from the edges and run in a zigzag shape which makes it possible to decrease the horizontal distance of the indents
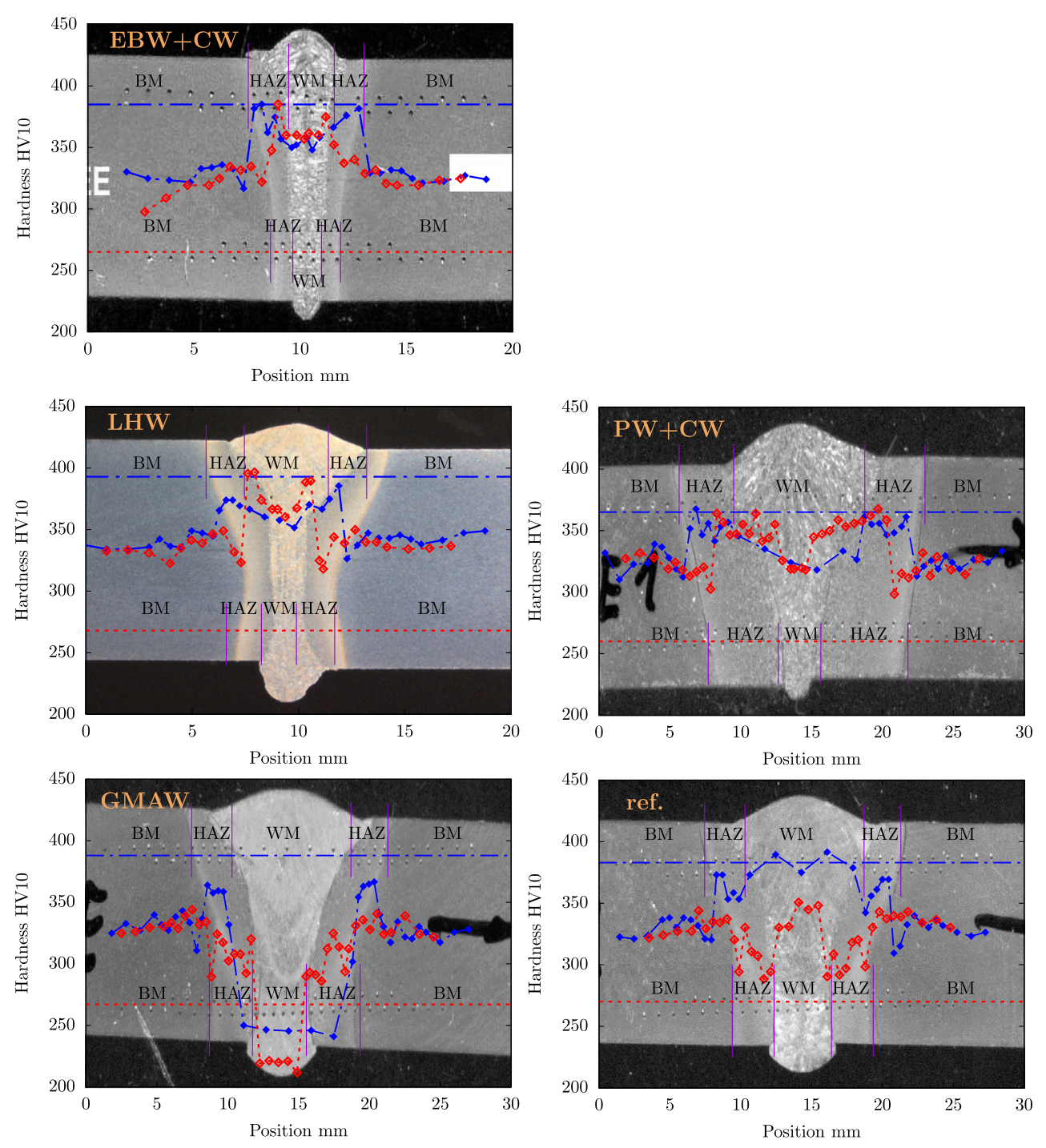

characteristic hourglass shape due to the additional GMA torch combined with a narrow heat affected zone. On the top side, a small undercut is visible, which is probably caused by the misalignment of the two sheets. This defect acts as a small notch and can be detrimental to fatigue properties of the weld. The $\mathrm{P}+\mathrm{CW}$ joints have, despite their square groove edge preparation, the characteristic V-shape. This is a result of the higher heat input of the plasma process, which also leads to the much bigger HAZ. From all investigated welds, the $\mathrm{P}+\mathrm{CW}$ welds have the smoothest weld seam geometry. For GMA welding, single $\mathrm{V}$ groove preparation was used, which is still visible in the resulting joint. Due to the lower energy density of the GMA process, two passes which can be easily distinguished on the etched cross-sections are necessary to join $8-\mathrm{mm}$ thick sheets. While the transition from weld bead to base material is smooth on the top side of the weld, the root side exhibits a somewhat angular form.
To characterize the microstructure in the weld metal of the different joints, LePera etching and scanning electron microscopy was used. Figure 8 shows all etched weld metals (on the left) and the corresponding scanning electron images (on the right). With the exception of the undermatched gas metal arc welds, all weld metals are a mixture of marteniste and tempered martensite. The weld metal of the $\mathrm{LH}$ welds consist mainly of fine needle shaped martensite and some autotempered martensite in between. The prior austenite grain size shows a large grain structure. The microstructure of the GMA welds with matching filler metal shows a similar mix of martensite and autotempered martensite, but with a slightly finer needle structure. The plasma welds show a much bigger prior austenite grain size and consist of martensite and autotempered martensite. In contrast to that, the gas metal arc welds with undermatching filler metal show a completely different microstructure. The weld metal consists mainly of ferrite and some martensite. 
Fig. 7 Comparison of etched cross-sections of all different fusion zones
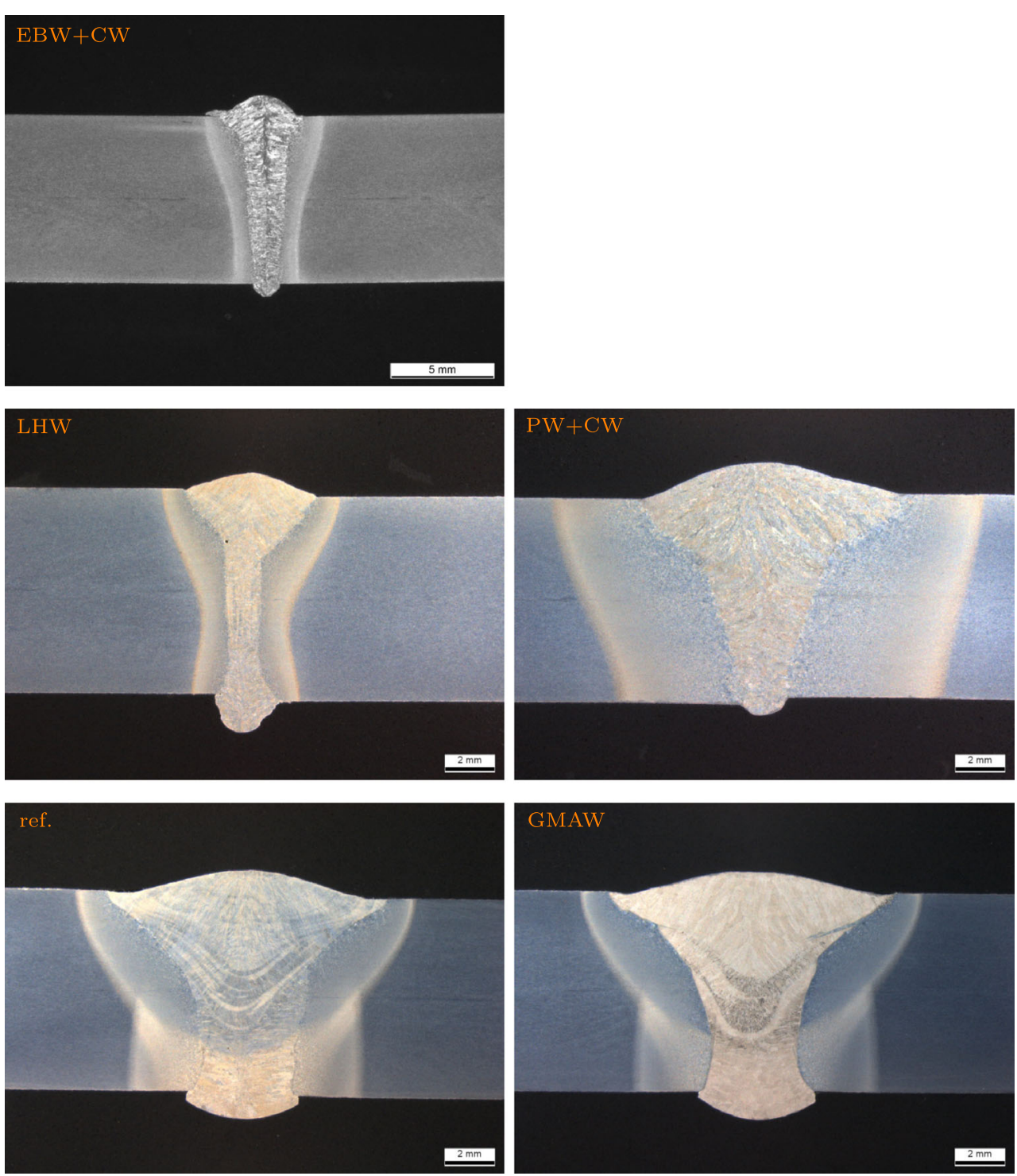

\subsection{Microprobe analysis}

The microprobe measurements show a significant influence of the different welding processes on the chemical composition of the weld metal. Figure 9 shows the content of the alloying elements chromium, nickel, and molybdenum in the base, weld, and filler metal for the different joints. The composition in the weld metal was measured using microprobe analysis. The contents for the base and filler metal were obtained from their data sheets. It can be seen that the chemical composition of the weld metal for the $\mathrm{EB}+\mathrm{CW}, \mathrm{LH}$, and $\mathrm{P}+\mathrm{CW}$ welds is closer to the base material than to the filler metal. For the GMA welds, the opposite is true. The numeric values above the boxes represent the dilution in the weld metal which was calculated using Eq. 1.

dilution $=\frac{m_{\mathrm{BM}}}{m_{\mathrm{WM}}}$

where:

$m_{\mathrm{BM}} \quad$ mass of base material in the weld metal

$m_{\mathrm{WM}}$ total mass of the weld metal

The main reason for the different dilutions in the weld zone lies in the different weld seam preparations for the different 
Fig. 8 Microstructure in the weld metal; LOM (left) and SEM (right)

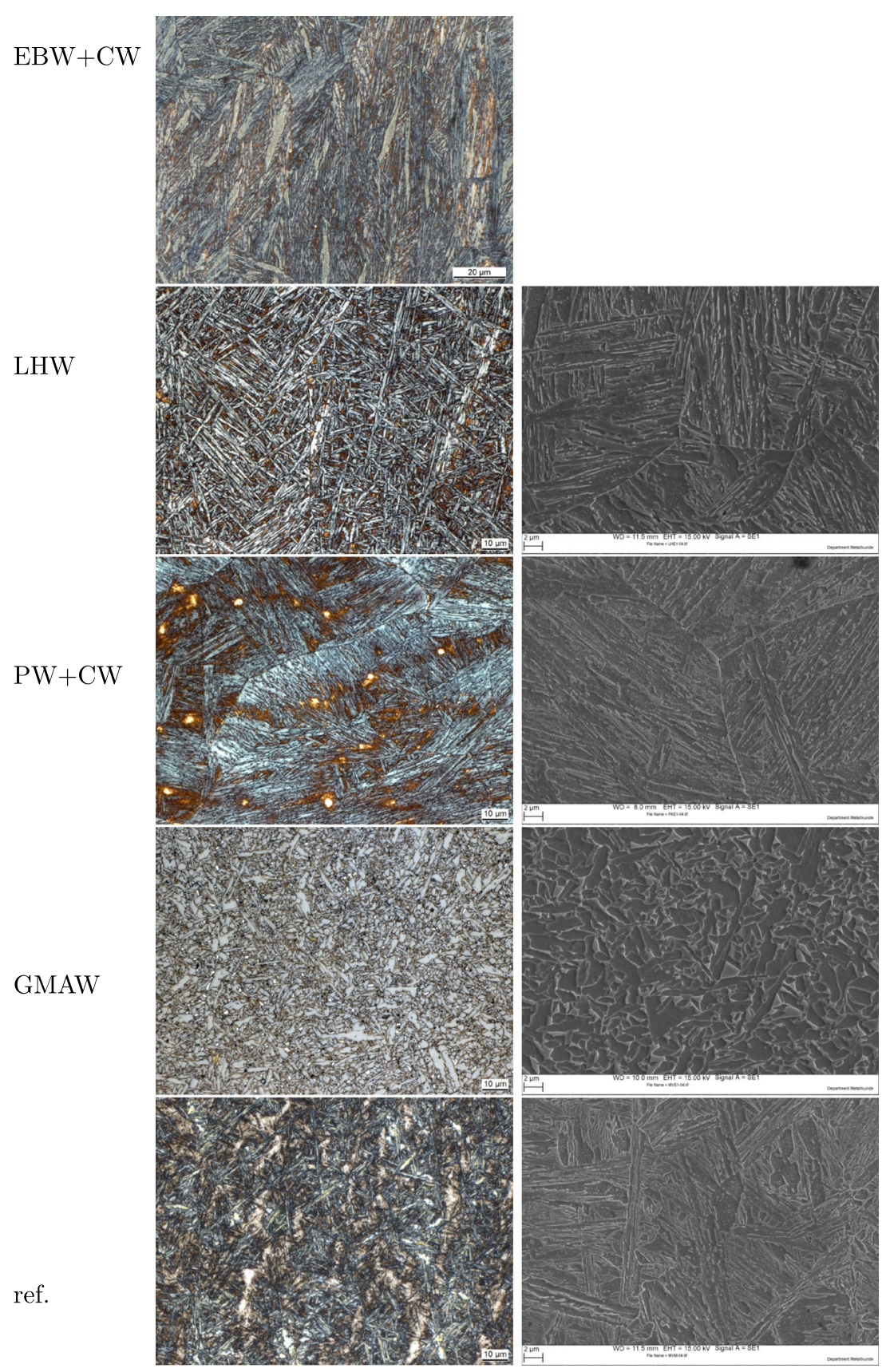

welding procedures. While the $\mathrm{EB}+\mathrm{CW}, \mathrm{LH}$, and $\mathrm{P}+\mathrm{CW}$

process use I-shaped edges with no gap, the GMA process needs a V-shaped edge with a welding head and gap (see Fig. 1). Thereby, more filler metal is needed to fill the weld seam of the gas metal arc welds (see Table 6). This leads to different recorded compositions in the weld metal (Fig. 9). The higher $\mathrm{Cr}, \mathrm{Ni}$, and Mo content in the resulting weld metal facilitates the martensite formation during cooling.

\section{Conclusions}

The weldability of 8-mm thick sheets of S960MC using undermatching filler metal with different welding processes 


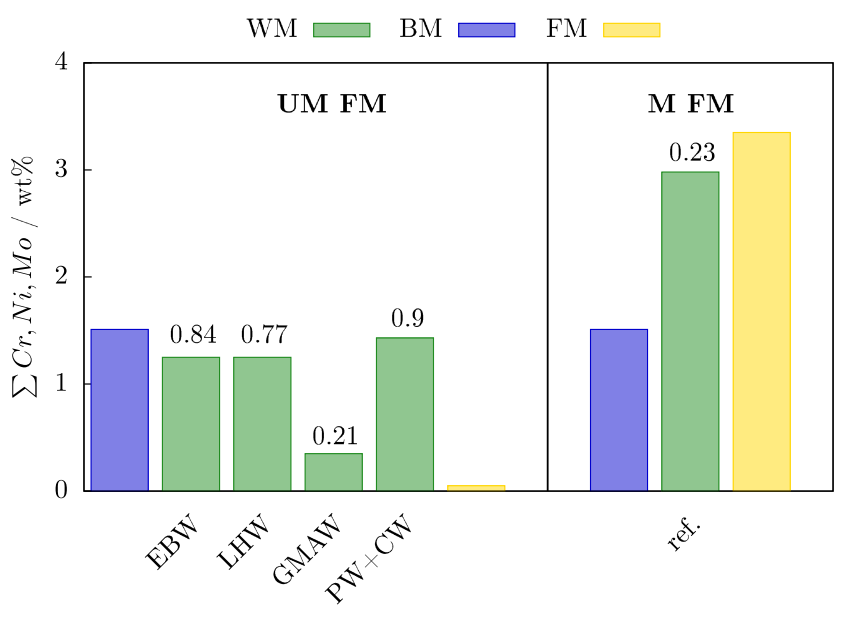

Fig. $9 \sum \mathrm{Cr}, \mathrm{Ni}, \mathrm{Mo}(\mathrm{wt} \%)$ in base, filler, and weld metal for all welding processes, the values above the green boxes are the dilution of the weld metal calculated using Eq. 1

was investigated. The reference samples were welded with standard gas metal arc welding using matching filler metal. Figure 10 shows the ultimate tensile strength in relation to the impact toughness at $-20{ }^{\circ} \mathrm{C}$ for the tested joints. A minimum tensile strength of $980 \mathrm{MPa}$ and a minimum impact toughness of $30 \mathrm{~J}$ define the target values of properties. The reference (circle) as well as the plasma welds safely reach these requirements. The data of the laser hybrid welds are more scattered, which results in bigger error bars. Using undermatching filler metal for gas metal arc welding of S960MC steel plates is not suitable, since the joints exhibit a significantly lower strength level. The following conclusions were drawn from this investigation:

- GMA welding of S960MC with matching filler metal produces joints with ideal strength and sufficient toughness.

- For $\mathrm{EB}+\mathrm{CW}, \mathrm{LH}$, and $\mathrm{P}+\mathrm{CW}$ welding, it is possible to use undermatching filler metal and obtain suitable mechanical properties.

- The dilution in the weld metal seems to be the key factor when using undermatching filler metal. A higher

Table 6 Dilution and the amount of $\mathrm{Cr}, \mathrm{Ni}$, Mo in the weld pool for the different welding processes

\begin{tabular}{lll}
\hline Process & Dilution & $\begin{array}{l}\sum \mathrm{Cr}, \mathrm{Ni}, \mathrm{Mo} \\
\mathrm{wt} \%\end{array}$ \\
\hline EBW+CW & 0.84 & 1.25 \\
LHW & 0.77 & 1.25 \\
P+CW & 0.9 & 1.43 \\
GMAW & 0.21 & 0.35 \\
Ref. & 0.23 & 2.98 \\
\hline
\end{tabular}

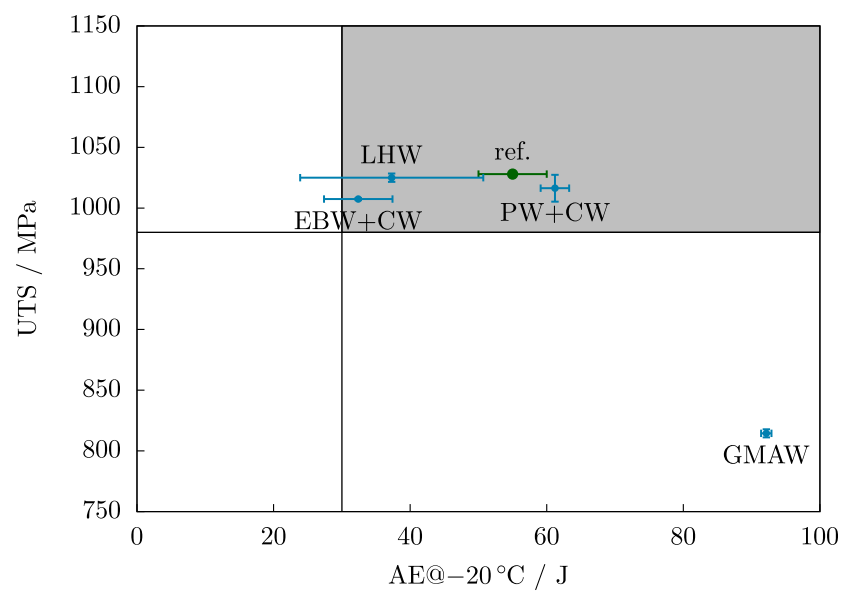

Fig. 10 Ultimate tensile strength in relation to impact toughness (VWT $(0 / 0))$ of the investigated joints

content of alloying elements $(\mathrm{Cr}, \mathrm{Ni}, \mathrm{Mo})$ in the weld pool is necessary for martensite formation.

- The microstructure in the weld zone of satisfying results consists mainly of martensite and autotempered marteniste.

Acknowledgments Open access funding provided by Graz University of Technology.

Funding Information The K-Project Network of Excellence for Metal JOINing is fostered in the frame of COMET - Competence Centers for Excellent Technologies by BMWFW, BMVIT, FFG, Land Oberösterreich, Land Steiermark, Land Tirol and SFG. The programme COMET is handled by FFG (österreichische Forschungsförderungsgesellschaft).

Open Access This article is distributed under the terms of the Creative Commons Attribution 4.0 International License (http:// creativecommons.org/licenses/by/4.0/), which permits unrestricted use, distribution, and reproduction in any medium, provided you give appropriate credit to the original author(s) and the source, provide a link to the Creative Commons license, and indicate if changes were made.

\section{References}

1. BS EN ISO 9016 (2012) Destructive tests on welds in metallic materials-impact tests-test specimen location, notch orientation and examination

2. Bunaziv I (2013) Optimization of parameters for fiber laser-MAG hybrid welding in shipbuilding applications. Ph.D thesis

3. Chao YJ, Ward JD, Sands RG (2007) Charpy impact energy, fracture toughness and ductile-brittle transition temperature of dual-phase 590 Steel. Mater Des 28(2):551-557

4. Engstróm H, Nilsson K, Flinkfeldt J, Nilsson T, Skirfors A, Gustavsson B (2001) Laser hybrid welding of high strength steels. In: Proceedings of ICALEO 2001, LIA (Orlando, FL), pp 125-134

5. Guo W, Crowther D, Francis JA, Thompson A, Liu Z, Li L (2015) Microstructure and mechanical properties of laser welded S960 high srength steel. Mater Des 85:534-548 
6. Guo W, Li L, Dong S, Crowther D, Thompson A (2017) Comparison of microstructure and mechanical properties of ultranarrow gap laser and gas-metal-arc welded S960 high strength steel. Opt Lasers Eng 91:1-15

7. ISO 148-1:2006 (2006) Metallic materials-Charpy pendulum impact test-Part 1: test method

8. ISO 6507-1 (2005) Metallic materials-Vickers hardness testPart 1: test method

9. ISO 6892-1:2009 (2009) Metallic materials-tensile testing-Part 1: method of test at room temperature

10. LePera FS (1980) Improved etching technique to emphasize martensite and bainite in high-strength dual-phase steel. JOM 32(3):38-39

11. Louden BS, Kumar AS, Garner FA, Hamilton ML, Hu WL (1988) The influence of specimen size on Charpy impact testing of unirradiated HT-9. J Nucl Mater 155-157(PART 2):662-667

12. Maurer W, Ernst W, Rauch R, Kapl S, Pohl A, Krüssel T, Vallant $\mathrm{R}$, Enzinger N (2012) Electron beam welding of a tmcp steel with 700 mpa yield strength. Welding in the World 56(9):85-94
13. Nagao A, Ito T, Obinata T (2008) $1100 \mathrm{MPa}$ class ultra high strength steel plates with excellent toughness and high resistance to delayed fracture for construction and industrial machinery. JFE Technical Report 11(11):13-18

14. ÖNORM EN ISO 15614-1 (2012) Specification and qualification of welding procedures for metallic materials - welding procedure test

15. Rauch R, Kapl S, Posch G, Radlmayr K (2012) High strength low alloy steel weldments with accommodated qualities to the base metal. BHM Berg- und Hủttenmảnnische Monatshefte 157(3):102-107

16. Schubert LE, Kumar AS, Rosinski ST, Hamilton ML (1995) Effect of specimen size on the impact properties of neutron irradiated A533B steel. In: Journal of Nuclear Materials, vol 225, pp 231-237

17. Wallin K (2001) Upper shelf energy normalisation for sub-sized Charpy-V specimens. Int J Press Vessel Pip 78(7):463-470

18. Zimmer P (2007) Zur Bewertung der Kaltrisssicherheit von Schweißverbindungen aus hochfesten Feinkornbaustählen. Ph.D thesis 